InOedia $\quad \begin{aligned} & \text { InMedia } \\ & \text { The French Journal of Media Studies }\end{aligned}$

5 | 2014

Media and Diversity

\title{
Serious Games? Four ideas that should be considered when it comes to introducing games into the classroom
}

\section{Eric Sanchez}

\section{(2) OpenEdition \\ Journals}

Electronic version

URL: http://journals.openedition.org/inmedia/814

DOI: $10.4000 /$ inmedia.814

ISSN: 2259-4728

Publisher

Center for Research on the English-Speaking World (CREW)

\section{Electronic reference}

Eric Sanchez, «Serious Games? Four ideas that should be considered when it comes to introducing games into the classroom », InMedia [Online], 5 | 2014, Online since 24 October 2014, connection on 08 September 2020. URL : http://journals.openedition.org/inmedia/814 ; DOI : https://doi.org/ 10.4000/inmedia.814

This text was automatically generated on 8 September 2020.

(c) InMedia 


\title{
Serious Games? Four ideas that should be considered when it comes to introducing games into the classroom
}

\author{
Eric Sanchez
}

1 Digital games represent now an economic sector with a more important turnover than the trade of books or music. Nowadays, playing is not a childhood activity anymore. Many adults are playing anytime and everywhere with a great diversity of devices such as computers, game consoles, digital tablets or smartphones. This high interest in games is not limited to frivolous activities as is attested by the development of an economic sector dedicated to games specifically designed for serious purposes, such as marketing or advertisement. Serious games are now used by companies to advertise for their products, by organizations to communicate about their activities and scientists to make research. Games are now considered to be a powerful new media which can be used for different serious purposes. However, our aim is to argue that, despite the majority of research works devoted to the game itself, the focused should be shift to the play, to the situation settled with the game.

2 Education is also affected by this gamification trend, often with the support of public authorities. However, using games to teach is not a new idea. The educational value of play has been recognized since Romanticism and Fröbel (1782-1852), a German pedagogue, who played an important role in spreading this idea among educators. In France, the word play entered the curriculum for the first time in the $19^{\text {th }}$ century but until recently, it has been mainly restricted to nursery school. This idea has been renewed since by the development of digital technologies that enable game design in various fields and offer new opportunities for teaching and learning.

Despite an enthusiastic debates and a growing body of research dedicated to digital play-based learning, we still lack knowledge to understand the consequences of using digital games for educational purposes. Thereafter, let us discuss four ideas that we 
think should be considered when introducing games into the classroom. More specifically, we need to identify the consequences of promoting game-based pedagogy regarding educators' responsibilities.

\section{Play vs. Game}

4 The French word jeu is ambiguous. It is used to name the game, the framework, the rules or the artifact used for this activity for instance, the expression jeu video (video games). In French, jeu also refers to either the situation designed with the game and the player, or the attitude of the player, the playing, considered as a free and frivolous activity. Some research fields focus more on the game itself. So do the researchers involved in the interdisciplinary academic field named "game studies". The research focuses on game design (computer science), on the influence of games (social sciences) or on the game experience (humanities). However, as Dewey stated that "a piece of art is not art" and that art is fundamentally interactive and experiential (Dewey, 1934), it is worth considering that play emerges from the interaction between a player and a game. In his seminal book Le jeu published in 1969, Henriot already emphasized the importance of distinguishing the game, as an artifact, and its usage: 'le jeu n'est pas dans la chose mais dans l'usage qu'on en fait' (Henriot, 1969). A shift from game to play enables the researcher to recognize that a digital artifact is not interactive in itself. It also enables him/her to put the emphasis on the situation designed with the game and on the interactions that emerge from that situation. When it comes to considering games designed for educational purposes, from a Piagetian point of view, we are led to consider that learning results from the adaptation of the learner to the game and thus, from the interactions within a given situation. As a result, these interactions can be named epistemic interactions. The expressions digital epistemic game and digital epistemic play sound much more relevant to name the artifact or the situation, than the expression serious game which is commonly used to name videogames designed for utilitarian purposes.

Due to the success of the idea that games have the power to make people do things that they would not do spontaneously, some researchers have tried to apply the characteristic of games to different artifacts and, in particular, to the web interfaces dedicated to social networks or e.marketing. Such gamification consists in increasing the level of the learner's commitment by offering challenges, developing a feeling of competence (with points, achievement badges and rewards) and stressing on the natural need for social interactions (competition or collaboration). Again, the focus on the game itself consists in a narrow view of what play means. The French word ludicisation (Genvo, 2013) sounds better especially when the purpose is to design a situation which combines playing and learning. Indeed, the latin roots of ludicisation, ludus, denotes both play and school work. Besides, the suffix icisation does not encompass the idea that it is possible to "make (fication or facere) the game" but to transform the situation.

\section{Play as a Phenomenological Experience}

6 Human experience is shaped by technologies which consist in a phenomenotechnique. Phenomenotechnique means that reality is not given but constructed by the 
instruments that we use to apprehend it. As a result, virtual reality is not opposed to reality but consists in another way to reach a phenomenon and simulation should not be opposed to reality. Simulation should be considered as an empirical experience "from a second type" (Varenne, 2006). Digital technologies, such as games, enable a new kind of phenomenological relationship with our world and as a consequence, a new way of knowing.

7 With games, this phenomenological experience is mainly based on the fact that the player has the freedom to take decisions, to shape strategies and imagine innovative solutions to the challenges that he has to face. He needs to perform according to his understanding of the situation. The continuous feedbacks provided by the game help him assess the consequences of his activity. Therefore, the situation consists of a space of reflexivity which offers the player/learner the opportunity to assess his way of thinking and behaving, to recognize success and failures, and to learn from them. Games are assessment tools and play-based learning consists in a form of experiential learning. The intrinsic value of playing lays in the fact that it is a phenomenological experience and not only in its motivational property (ie. making possible that people accepts to learn something that is not motivating in itself).

\section{Play as Ideology}

8 The phenomenological experience of play depends on the freedom offered by the game and the rules that frame this freedom. Therefore, this freedom is a legaliberté (Duflo, 1997). The players have the opportunity to take decisions and to shape strategies in spite of a number of limits set by the constraints of the game. The decisions of the player are directed by these constraints as each action provokes an immediate feedback and the player can assess the relevance of his decisions according to an "epistemic frame" (Shaffer, 2006) which is embedded in the game. This epistemic frame is a set of knowledge, skills, values and a way of making decisions that guide the behavior of the player. The player takes decisions that he would not have spontaneously taken. He is manipulated by the game. In Ecoville (ADEME, 2010), a game dedicated to sustainable development education, a winning strategy consists in multiplying wind wheels without taking into consideration their social impact. By playing Spore (Electronic Arts, 2009), a Sim-like videogame, the player is an intelligent designer who decides the direction of the evolution of his creature. Thus, the rules of this God-game are contradictory with the Darwinian concepts of necessity and chance. The epistemic frame embedded into the game depends on the choices and decisions of the game designer. Therefore, games represent ideologies and "playing the games can become a persuasion to believe in the general ideology surrounding them" (Sutton-Smith, 1997), at least while playing. This ideology supported by games is often mentioned to criticize games that are considered to glorify violence, sexism or racism. Indeed, each game is based on a simulation which represents a specific field. In the case of educational uses, teachers may benefit from games that are considered to be authentic in regard to the learning field. In this respect, mixed and augmented reality, which enable to hybridize the physical reality with virtual reality, offer new opportunity to design realistic gaming environments where the players have to face complexity and non-deterministic problems. Another approach for the design of epistemic games consists in developing metaphors which concentrate the attention of the player on the core dimension of a 
problem. However, in all cases, implementing a game-based pedagogy implies that educators are able to recognize the domain of validity of the knowledge model embedded into a game and the values that are put forward.

\section{Play as Illusion}

9 According to Winnicott (1971), play occurs at the intersection of what is objectively perceived and what is subjectively conceived. Therefore, play is an illusion. This illusion results from the fact that, within the game, the player is a puppet master who is not able to say if what happens results from his subjective desire or from an external and objective reality. The puppet of the game is called avatar. An avatar is a projective identity. The player immerses into a role and an environment but he is protected from the consequences of his errors and failures that are assumed by his avatar. This avatar is also a projective identity in a second meaning. The avatar becomes an ideal figure in which the player can project his ideas, values and desires and, therefore, find the opportunity of self-development.

The puppet master paradox illustrates the fact that, in order to become a learner, the player of a serious game based on role-play or simulation, needs to trust the puppet that he controls. He needs to accept to learn from events that he has provoked, from discoveries that result from his own decisions. As a consequence, the debriefing which follows up on the time devoted to playing leads to the disillusion of the player. This debriefing consists in making the learning explicit and enables the transfer of knowledge. Indeed, through this phase, the status of the knowledge changes. This knowledge is not anymore a tool used to solve problems within the game but a reference that can be used to solve a problem in a situation that is not a game anymore. Learning implies leaving the game and the teacher therein plays an important role.

\section{Conclusion}

11 By implementing a game-based learning approach, educators have to face difficult challenges. These challenges lay in the characteristics of the game itself and the relevance of its content according to the subject to be taught. These challenges consist also in allowing the emancipation of the learners. This emancipation depends on the capacity of educators to help the player to leave the game in order to become a learner by taking a critical look at his play experience. This is related to media education and teachers should receive a specific training in this respect.

But epistemic games also offer new opportunities for educators. These opportunities do not lay only in the motivating power of games. Epistemic games carry out the implementation of learner-centered approaches for teaching based on experiential learning where the challenges they have to face enable the learner to develop the capacity to deal with complex problems. This occurs in a safe space where errors and failures are allowed. In this perspective, a game-based pedagogy is not a way to trick people into leaning something that is supposed not to be attractive. The arguments for introducing serious play into the classroom lay in its intrinsic pedagogical value. 


\section{BIBLIOGRAPHY}

Dewey, John. Art As Experience. New York : Penguin, 1934.

Duflo, Colas. Jouer et Philosopher. Paris : Presses Universitaires de France, 1997.

Genvo, Sébastien. "Penser les phénomènes de ludicisation à partir de Jacques Henriot." Sciences du jeu, 1 (2013): 1-15.

Henriot, Jacques. Le Jeu. Paris : Presses Universitaires de France, 1969.

Schaffer, David Williamson. "Epistemic frames for epistemic games." Computers and Education, 46.3 (2006): 223-234.

Sutton-Smith, Brian. The Ambiguity of Play. Cambridge: Harvard University Press, 1997.

Varenne, Franck. Les Notions de métaphore et d'analogie dans les épistémologies des modèles et des simulations. Paris : Petra, 2006.

Winnicott, Donald Woods. Playing and Reality. London : Tavistock Publications, 1971.

\section{NOTES}

1. 'Play does not lay in the artifact but in the use of the artifact.'

\section{AUTHOR}

\section{ERIC SANCHEZ}

Ecole Normale Supérieure Lyon 